\title{
Perkembangan Politik Hukum dan Kebutuhan Hukum Keimigrasian Indonesia: Menjawab Sebagian, Melupakan Selebihnya ${ }^{1}$
}

\author{
The Development of Legal Policy and Legal Needs of Indonesian \\ Immigration Law: Answered Partially, Forget the Rest
}

\author{
Bilal Dewansyah \\ Departemen Hukum Tata Negara, Fakultas Hukum, Universitas Padjadjaran \\ Jln. Imam Bonjol No. 21, Bandung, 40132, Jawa Barat, Indonesia. \\ Tel./Fax.+62-22-2508514E-mail: bilal.dewansyah@unpad.ac.id
}

Submitted: Jul 13, 2015; Reviewed: Jul 24, 2015; Accepted: Aug 3, 2015

\begin{abstract}
The replacement of the immigration law, from Law No. 9 of 1992 to Law No. 6 of 2011 reflected the development of immigration legal policy. As a branch of administrative law that has dynamic character, the reform immigration laws should address the immigration legal needs in practice. This paper discusses the development of Indonesian immigration legal policy and to what extent these developments address the immigration legal needs. Based on the author analyses, it can be concluded, firstly, the development of immigration legal policy, in legal direction context, emphasized to face the impact of globalization both positive and negative effects, and other developments in the future. In legal substances aspect, the current immigration legal policy change various principles immigration laws, such as the principle of selective policies are balanced with the principle of respect for human rights, although in certain settings are not in line with human rights (as in the case of the period of temporary prohibition to leave Indonesia, that can be extended continuously). In legal form and scope context, Indonesian immigration legal policy today, is more concerned with the rules of immigration law in detail than ever before. Secondly, the development of immigration legal policy answered the immigration legal needs particularly, such as in the case of human smuggling, but forget the rest of the immigration legal needs, in terms of the handling of illegal immigrants, asylum seekers and refugees.
\end{abstract}

Keywords: Immigration Law; Immigration Legal Needs; Legal Policy

\footnotetext{
Substansi tulisan berasal dari sebagian hasil Penelitian Unggulan Fakultas Hukum Unpad tahun 2013, berjudul: Politik Hukum Keimigrasian Indonesia Menurut Undang-Undang Nomor 9 Tahun 1992 dan Undang-Undang Nomor 6 Tahun 2011 tentang Keimigrasian, yang disesuaikan dengan perkembangan terakhir oleh penulis. Penulis berterima kasih kepada para personil tim peneliti, yaitu Susi Dwi Harijanti, Ph.D. selaku Ketua Peneliti, Dr. Indra Perwira dan Dr. Ali Abdurahman selaku Anggota Peneliti, Wicaksana Dramanda (Peneliti PSKN FH Unpad) dan Neneng Widasari (mahasiswa tingkat akhir Fakultas Hukum Unpad, Program Kekhusuan HTN), yang telah berkontribusi terhadap seluruh proses penelitian ini.
} 


\begin{abstract}
Abstrak: Penggantian undang-undang keimigrasian dari Undang-Undang No. 9 Tahun 1992 ke Undang-Undang No. 6 Tahun 2011 mencerminkan adanya perkembangan politik hukum keimigrasian. Sebagai cabang hukum administrasi yang berkarakter dinamis, pembaruan politik hukum keimigrasian semestinya menjawab kebutuhan hukum keimigrasian dalam praktik. Tulisan ini membahas perkembangan politik hukum keimigrasian Indonesia dan sejauh mana perkembangan tersebut menjawab kebutuhan hukum kimigrasian Indonesia. Berdasarkan pembahasan penulis, dapat disimpulkan, pertama, terdapat perkembangan arah politik hukum keimigrasian yang ditekankan untuk lebih dapat menghadapi dampak globalisasi baik dampak positif maupun dampak negatif, dan perkembangan lainnya di masa depan. Dari segi substansi, politik hukum keimigrasian saat ini mengubah berbagai prinsip-prinsip hukum keimigrasian sebelumnya, seperti prinsip kebijakan selektif yang diimbangi dengan prinsip penghormatan HAM, walaupun dalam pengaturan tertentu tidak sejalan dengan HAM (seperti dalam hal jangka waktu keputusan pencegahan yang dapat diperpanjang terus menerus). Dari segi bentuk dan jangkauan, politik hukum keimigrasian Indonesia saat ini, lebih banyak mengatur kaidah-kaidah hukum keimigrasian dengan rinci dibandingkan sebelumnya. Kedua, perkembangan politik hukum keimigrasian, terutama berdasarkan UU No. 6 Tahun 2011 menjawab sebagian kebutuhan hukum keimigrasian Indonesia, seperti untuk kasus penyelundupan manusia, namun melupakan kebutuhan hukum keimigrasian yang selebihnya, dalam hal penanganan imigran illegal, pencari suaka dan pengungsi.
\end{abstract}

Kata Kunci: Politik Hukum, Hukum Keimigrasian, Kebutuhan Hukum Keimigrasian

\section{PENDAHULUAN}

Setelah kurang lebih 19 tahun berlaku, Undang-Undang No. 9 Tahun 1992 tentang Keimigrasian (UU No. 9/1992) digantikan dengan Undang-Undang Nomor 6 Tahun 2011 tentang Keimigrasian (UU No. 6/2011). Penggantian undang-undang yang pada prinsipnya merupakan perubahan komprehensif, biasanya dilakukan salah satunya karena "esensinya berubah."2 Perubahan esensi peraturan perundang-undangan, juga dapat mencerminkan perubahan, atau setidak-tidaknya, perkembangan politik hukum, khususnya politik perundang-undangan. Artinya, ada perkembangan politik hukum keimigrasian sejak lahir UU No. 6/2011.

2 Lihat angka 238 Lampiran II UU No. 12/2011 tentang Pembentukan Peraturan Perundang-undangan. Sebelumnya ketentuan serupa juga diatur dalam angka 199 Lampiran UU No. 10 Tahun 2004.
Pertanyaannya, sejauhmana perkembangan politik hukum keimigrasian itu tercermin dalam UU No. 6/2011? Aspek-aspek hukum keimigrasian apa saja yang berubah secara signifikan, sehingga yang dilakukan adalah pembentukan undang-undang baru, bukan perubahan parsial?

Saat menghadiri pengambilan suara untuk persetujuan DPR terhadap RUU Keimigrasian tahun 2011, Menteri Hukum dan Hak Asasi Manusia (HAM) saat itu, Patrialis Akbar menyatakan, bahwa Indonesia tidak lagi bersikap diskriminatif terhadap hasil kawin campur antara orang asing dengan warga Indonesia. ${ }^{3}$ Menurutnya

\footnotetext{
Rakyat Merdeka Online. (2011). "UU Imigrasi Disahkan, Pemerintah Tak Lagi Diskriminatif Terhadap Kawin Campur", Kamis, 07 April, Dikutip pada laman website: http://www.rmol.co/ read/2011/04/07/23499/UU-Imigrasi-Disahkan,Pemerintah-Tak-Lagi-Diskriminatif-TerhadapKawin-Campur-. [Diakses 30 Juni 2015].
} 
UU Keimigrasian baru mengubah antara lain: ${ }^{4}$ anak hasil pernikahan campur tersebut bisa langsung menjadi warga Indonesia dan bisa tetap tinggal di negeri ini. Anak hasil kawin campur dengan orang asing dan tinggal di luar negeri, tapi tiba-tiba ingin tinggal di Indonesia, maka pemerintah langsung memfasilitasi dengan diberi identitas sebagaimana warga negara dan berlaku selama 2 tahun (lalu dapat ditingkatkan menjadi izin tinggal tetap di Indonesia). Warga negara asing hasil kawin campuran yang lahir di Indonesia, tapi tidak memilih tinggal di Indonesia, menurut Patrialis akan diberi izin tinggal tetap di Indonesia dengan waktu yang tidak terbatas dan biayanya gratis. Orang asing yang nikah dengan warga Indonesia pemegang identitas diperkenankan mencari nafkah di negeri ini.

Berbeda dengan pandangan di atas, menurut Fachri Hamzah, yang saat itu merupakan Ketua Panja RUU Keimigrasian, setidaknya ada lima paradigma yang digunakan sebagai landasan filosofis dan sosiologis dalam UU Keimigrasian yang baru ini. ${ }^{5}$ Pertama, mencegah penyalahgunaan wewenang. Kedua, reformasi birokrasi dan pelayanan publik yang efektif, efisien, dan memiliki kepastian hukum. Ketiga, pembaruan penyelenggaraan fungsi keimigrasian yang berbasis keada sistem informasi dan manajemen keimigrasian. Keempat, memodernisasi pendekatan keamanan dengan penghormatan hak asasi manusia.

\footnotetext{
Ibid.

HukumOnline. (2011). "UU Keimigrasian Akhirnya Disahkan", Kamis, 7 April, http://new.hukumonline.com/berita/baca/lt4d9d70fc099bd/ uu-keimigrasian-akhirnya-disahkan. [Diakses 30 Juni 2015].
}

Kelima, memajukan kesejahteraan masyarakat dengan mendukung peningkatan investasi, pariwisata dan mengayomi hubungan sosial budaya bangsa Indonesia dalam pergaulan internasional.

Dari kedua pandangan di atas, para pembentuk undang-undang pun tidak selalu memiliki persepsi yang sama terhadap undang-undang yang sama. Walaupun tidak saling bertentangan, namun kedua pandangan di atas mencerminkan bahwa perkembangan politik hukum keimigrasian perlu didentifikasi lebih lanjut. Kalau pun telah diketahui perkembangan signifikan politik hukum keimigrasian, apakah peraturan pelaksanaan undang-undang terbaru secara konsisten sejalan dengan politik hukum yang ditetapkan dalam UU No. 6/2011?

Secara substansi, hukum keimigrasian yang pada hakekatnya merupakan dari hukum administrasi khusus (bijzondere administratif recht $)^{6}$, berkembang dinamis. ${ }^{7}$ Dengan karakter tersebut, upaya mereformasi ketentuan-ketentuan hukum keimigrasian merupakan suatu kebutuhan, atau dalam rangka merespon kebutuhan.

\footnotetext{
Sebagaimana dikatakan Bagir Manan, bahwa hukum keimigrasian adalah kaidah hukum administrasi negara khusus (bijzondere administratif recht). Lihat Bagir Manan. (2000). "Hukum Keimigrasian dalam Sistem Hukum Nasional”, makalah yang disampaikan pada Rapat Kerja Nasional Keimigrasian, Jakarta: Ditjend Keimigrasian Departemen Hukum dan Perundang-undangan, 14 15 Januari, hlm. 8.

Bradley dan Ewing mencontohkan hal ini dalam hal pengujian tindakan administratif, termasuk dalam bidang keimigrasian, termasuk sebagai salah satu area (urusan) pemerintahan yang menimbulkan berbagai kasus pengujian lebih dari bidang lainnya. Lihat A.W. Bradley, K.D. Ewing. (2007). Constitutional and Administrative Law, $14^{\text {th }}$ Ed, Harlow (England) : Pearson Education Limited, hlm. 725.
} 
Diundangkannya UU No. 6/2011 idealnya dapat dipandang sebagai salah upaya untuk merespon kebutuhan hukum keimigrasian, yang sangat mungkin disebabkan karena kondisi dinamis lingkungan internal (dalam negeri) maupun lingkungan ekternal (aspek hubungan internasional). Namun demikian, apakah penggantian undang-undang keimigrasian ini menjawab kebutuhan hukum keimigrasian nasional saat itu atau di masa yang akan datang?

Tulisan ini membahas kedua hal di atas, yaitu: Pertama, perkembangan politik hukum apa saja yang terjadi dari pergantian UU keimigrasian? Kedua, sejauh mana politik hukum keimigrasian dalam undang-undang baru telah mengakomodasi kebutuhan hukum keimigrasian nasional?

\section{METODE}

Tulisan ini menggunakan pendekatan yuridis-normatif dengan metode deskriptif analitis. Kaidah-kaidah hukum keimigrasian baik dalam UU No. 9/ 1992 maupun UU No. 6/ 2011 diteliti perbedaan dan persamaannya dikaitkan dengan prinsip-prinsip hukum keimigrasian. Selain itu, perkembangan politik hukum keimigrasian juga dikaji dari latar belakang pembentukan masing-masing undang-undang tersebut untuk mendapatkan faktor-faktor yang mempengaruhi perkembangan politik hukum keimigrasian.

Pembahasan mengenai faktor-faktor tersebut juga dikaitkan dengan kasus-kasus dan peristiwa-peristiwa penting yang mempengaruhi perkembangan politik hukum keimigrasian berdasarkan kedua undang-undang di atas, khususnya untuk melihat sejauh mana politik hukum keimgrasian mengako- modasi kebutuhan hukum keimigrasian nasional.

\section{ANALISIS DAN PEMBAHASAN}

\section{Politik Hukum Keimigrasian}

Dalam tulisan ini, politik hukum diartikan sebagai kebijakan yang berkenaan dengan hukum atau kebijakan dalam bidang hukum, ${ }^{8}$ dengan ruang lingkup berupa arah hukum, bentuk hukum, isi (substansi) hukum dan jangkauan politik hukum. ${ }^{9}$ Arah hukum merupakan tujuan yang hendak diwujudkan atau dicapai, sementara bentuk hukum menunjukkan adanya berbagai bentuk peraturan perundang-undangan dan isi hukum berkaitan dengan substansi yang diatur dalam suatu peraturan perundang-undangan. ${ }^{10}$

Menurut Bintan R. Saragih, arah hukum, khususnya dalam bentuk hukum berupa peraturan perundang-undangan, dapat tercermin dari pertimbangan (konsideran) dan penjelasan umum suatu peraturan perundang-undangan, khususnya undang-undang. Terkait dengan jangkauan politik hukum, Sri Soemantri menegaskan hal tersebut terkait batasan politik hukum yaitu baik terhadap ius constitutum maupun ius constituendum. ${ }^{11}$

8 H.R.T. Sri Soemantri M. (2014). Hukum Tata Negara Indonesia Pemikiran dan Pandangan, Bandung: Remaja Rosdakarya, hlm. 122.

$9 \quad$ Idem., hlm. 125. Pendapat Sri Soemantri mengenai jangkauan politik hukum dikemukakan dalam kuliahnya di Program Magister Ilmu Hukum Fakultas Hukum Unpad pada mata kuliah Politik Hukum tanggal 11 September 2009.

10 Ibid.

11 Menurut H.R.T. Sri Soemantri, pendapat Padmo Wahjono politik hukum menunjukkan sesuatu yang hendak dibentuk atau diadakan (ius contituendum), sementara politik hukum menurut pendapat T.M. Radhie mencerminkan baik pada ius constitum dan ius constituendum. Idem., hlm. 130. Menurut Mahfud M.D., pendapat Radhie tersebut menganggap politik hukum sebagai "ra- 
Dalam hal ini, jangkauan politik hukum suatu negara secara umum baik pada hukum yang sedang berlaku di wilayah negara maupun hukum yang akan dibentuk atau diadakan/dicita-citakan di masa mendatang.

Secara spesifik, M. Iman Santoso menegaskan dalam hal hukum keimigrasian Indonesia, politik hukum keimigrasian adalah nilai-nilai, pilihan nilai-nilai, yang diserap dalam kaidah hukum keimigrasian, yang digunakan dalam pengaturan lalu-lintas orang yang keluar-masuk wilayah Republik Indonesia, serta pengawasan orang asing di wilayah hukum Indonesia. ${ }^{12}$ Nilai-nilai dan pilihan-pilihan nilai di atas tentu saja ditujukan untuk mencapai tujuan yang hendak dicapai dalam kaidah-kaidah hukum keimigrasian. Pilihan atas nilai-nilai tersebut secara konkrit berupa pilihan terhadap prinsipprinsip politik hukum keimigrasian yang akan melandasi dalam kaidah-kaidah hukum keimigrasian.

\section{Keimigrasian sebagai Wujud Kedaulatan Interdependen}

M. Iman Santoso menegaskan, "Apabila membicarakan fungsi keimigrasian, maka tidak bisa tidak, dikaitkan dengan teori kedaulatan, karena teori ini merupakan landasan dasar bekerjanya fungsi keimigrasian."13 Berdasarkan landasan tersebut, negara berwenang untuk menentukan izin bagi warga

jutan" antara ius constitutum dengan ius constituendum. Moh. Mahfud MD. (2006), Membangun Politik, Menegakkan Konstitusi, Jakarta: LP3ES, hlm. 13.

12 M. Iman Santoso. (2004). Perspektif Imigrasi Dalam Pembangunan Ekonomi dan Ketahanan Nasional, Jakarta: UI Press, hlm. 60.

13 M. Iman Santoso. (2007). Perspektif Imigrasi Dalam United Nation Convention Against Transnational Organized Crime, Jakarta: Perum Percetakan Negara - RI, hlm. 18. negaranya untuk bepergian ke luar negeri dan kondisi-kondisinya, dan menentukan izin masuk dan penetapan orang asing di negara tersebut. ${ }^{14}$

Dalam pemikiran klasik, kedaulatan diasosiasikan dengan kekuasaan tertinggi (supreme), mutlak (absolute), dan tidak terbagi (indivisible). ${ }^{15}$ Jean Bodin, peletak dasar teori kedaulatan negara, membatasi kedaulatan hanya berada di tangan negara dan hanya dalam (wilayah) negara. ${ }^{16}$ Dalam hal ini, negara dipandang sebagai satusatunya organisasi tertinggi, yang berbeda dengan organisasi lainnya. Pada setiap organisasi pasti terdapat kekuasaan, namun hanya negara yang memiliki kekuasaan tertinggi dibandingkan organisasi lainnya, yaitu kedaulatan.

Dipandang dari aspek kedaulatan klasik ini, karakteristik dari ketentuan-ketentuan hukum di bidang keimigrasian, meminjam istilah Gill, mencerminkan absolute and uncontrolled discretion (diskresi yang absolut dan tanpa kontrol) atau sovereign power (kekuasaan berdaulat) dari negara. ${ }^{17}$ Namun demikian, menurut Pemberton, konsep kedaulatan klasik seperti yang dikemukakan Bodin tersebut, cenderung mengarah pada tirani, ${ }^{18}$ walaupun konsep tersebut merupakan bentuk respon Bodin pada zamannya terutama di Perancis dimana penguasa tidak mampu mengatasi dominasi

14 Guy S. Goodwin Gill. (1978). Internasional Law and Movement of Persons Between States, Oxford: Clarendon Press, hlm. 3.

15 Jo-Anne Pemberton. (2009). Sovereignty: Interpretations, Hampshire - New York: Palgrave Macmilan, hlm. 1.

16 Ibid.

17 Guy S. Goodwin Gill, Loc.Cit., hlm. 3.

18 Jo-Anne Pembarton, Op. Cit., hlm. 26. 
kekuasaan religius yang mendiskreditkan kelompok religius minoritas. ${ }^{19}$

Dalam perkembangannya, kedaulatan negara dihadapkan pada fenomena globalisasi. Terkait hal ini, Anne L. Clunan mencatat sejumlah literatur akedemik yang melakukan studi terhadap erosi kedaulatan internal negara akibat fenomena globalisasi atau globalization's erotion of state control (erosi globalisasi terhadap kontrol negara), seperti yang dilakukan oleh Keohane and Nye (1989), Rosenau (1990), Strange (1996), Mathews (1997), dan Slaughter 2004. ${ }^{20}$

Studi tersebut menggambarkan erosi secara de facto terhadap kedaulatan internal negara, di mana terjadi reduksi kemampuan negara untuk mengendalikan hal-hal yang terjadi di dalam batas wilayah negara di bawah tekanan ekonomi dan arus informasi (global). ${ }^{21}$ Bahkan menurut Pamberton, di sejumlah literatur, globalisasi dianggap telah menyebabkan "kematian negara-negara berdaulat." ${ }^{22}$ Di sisi lain, terdapat pandangan bahwa peran negara nasional dalam globalisasi justru akan semakin penting. Linda Weiss, misalnya, mengatakan: "negara-

19 Konsep tersebut merupakan bentuk respon Bodin terhadap lemahnya peran penguasa di Perancis yang tidak mampu mencegah terjadinya perang sipil dan agama tahun 1572.Peristiwa puncak dari perang sipil dan agama yang dikritik oleh Bodin adalah peristiwa pembunuhan masal penganut Kristen Protestan di mana lebih dari 3000 orang dipenggal di Paris dan antara 10.000 sampai dengan 20.000 orang terbunuh antara tanggal 2324 Agustus 1572. Lihat Idem., hlm. 23.

20 Anne L. Clunan. "Redefining Sovereignty: $\mathrm{Hu}-$ manitarianism's Challenge to Sovereign Immunity" dalam Noha Shawki and Michaelene Cox (ed). (2009). Negotiating Sovereignty and Human Rights Actors and Issues in Contemporary Human Rights Politics, England: Ashgate, hlm. 8.

21 Ibid.

22 Jo-Anne Pembarton, Loc.Cit., hlm. 1. negara bangsa akan berperan lebih besar daripada berkurang (perannya). Menguatnya peran negara-negara bangsa dalam kenyataan akan meningkatkan pembangunan ekonomi dunia." ${ }^{23}$

Selain pendapat-pendapat di atas yang saling bertentangan, terdapat pendapat yang menganggap bahwa di satu sisi globalisasi memiliki dampak pada kedaulatan negara namun di sisi lain hal tersebut tidak menjadikan kedaulatan negara menjadi tidak relevan. ${ }^{24}$ Hal tersebut mencerminkan perlunya rekonseptualisasi kedaulatan, meminjam istilah Pamberton, untuk mengakomodasi peningkatan batas-batas wilayah yang kabur dan politik dunia yang multidimensional. ${ }^{25}$ Dari pendapat di atas, konsep kedaulatan negara perlu menyesuaikan perubahan lingkungan eksternal, dalam hal ini globalisasi.

Namun demikian, menurut Krasner, tantangan semacam globalisasi bukan merupakan hal baru bagi negara-negara bangsa, seperti migrasi yang besar pada abad ke19. ${ }^{26}$ Dalam pandangan Krasner, globalisasi terkait dengan salah satu aspek kedaulatan, yaitu kedaulatan interdependen yang mengacu pada pengendalian negara terhadap pergerakan lintas batas negara. ${ }^{27}$ Menurut Krasner, hilangnya kedaulatan interdependen tidak menyebabkan hilangnya kedaulatan domestik suatu negara dalam mengambil keputusan yang otoritatif, namun

23 Dikutip dari Catherine Dauvergne (2008). Making People Illegal What Globalization Means for Migration and Law, Cambridge - New York : Cambridge University Press, hlm. 31.

24 Jo-Anne Pamberton, Loc.Cit., hlm. 1.

25 Ibid.

26 Stephen D. Krasner. 1(999),.Sovereignty: Organized Hypocrisy, Pricenton: Pricenton University Press, hlm. 223.

27 Idem., hlm. 9. 
hal tersebut mengurangi aspek kedaulatan domestik. ${ }^{28}$ Bagi Krasner, jika sebuah negara tidak dapat mengatur apa yang melewati batas negaranya, maka negara tersebut tidak dapat mengendalikan apa yang akan terjadi di wilayah negaranya. ${ }^{29}$ Dalam hal ini, Krasner sendiri mengakui bahwa salah satu aspek dari kedaulatan negara dapat menjadi tidak efektif akibat globalisasi, walaupun tidak mematikan seluruh aspek kedaulatan negara.

Dari perkembangan konsep kedaulatan di atas, keimigrasian terkait dengan aspek kedaulatan interdependen atau kemampuan negara untuk mengontrol/ mengendalikan keluar masuknya orang pada wilayah negara. Di sisi lain, ketentuan-ketentuan keimigrasian merupakan wujud dari kedaulatan domestik negara, terutama untuk menentukan siapa saja orang yang dapat keluar dan masuk pada wilayah negara tersebut. Dengan demikian, keimigrasian terkait dengan isu pengendalian (control) lalu lintas orang lintas negara dan kewenangan (authority) untuk menerapkan ketentuan-ketentuan keimigrasian.

Dapat terjadi suatu negara memiliki hukum keimigrasian yang sangat ketat, namun memiliki kemampuan yang lemah dalam mengendalikan lalu lintas orang yang masuk atau ke luar pada wilayahnya atau sebaliknya. Dalam hal ini, tesis bahwa keimigrasian merupakan the last bastions of sovereignty ${ }^{30}$ (benteng terakhir kedaulatan)

28 Idem, hlm. 13.

29 Ibid.

30 Stephen Legomsky. "The Last Bastions of State sovereignty Immigration and Nationality Go Global", dalam Andrew C. Sobel (ed). (2009). Challenges of Globalization Immigration, Social Welfare, Global Governance, London - New York: Routledge, hlm. 44; Catherine Dauvergne, Op.Cit., hlm. 2. sangat bergantung pada pelaksanaan kedua aspek kedaulatan tersebut, terutama dalam merespon fenomena migrasi global.

Perkembangan Arah, Substansi, Bentuk dan Jangkauan Politik Hukum Keimigrasian

Perkembangan arah hukum keimigrasian

Dari segi arah hukum, terdapat perkembangan politik hukum dalam UU No. 9/1992 ke UU No. 6/2011. UU No. 9/1992 tidak sekedar mewujudkan kedaulatan Indonesia sebagai dasar keimigrasian, tercermin bahwa arah politik hukum keimigrasian dalam UU No. 9/1992 dalam rangka menyatukan, menyempurnakan berbagai peraturan perundang-undang di bidang keimigrasian yang tersebar. Meminjam perkataan $\mathrm{M}$. Iman Santoso, "UU No. 9/1992 telah berfungsi menjadi ketentuan "payung" bagi pelaksanaan tugas keimigrasian." 31

Dengan demikian, UU No. 9/1992 mencerminkan politik hukum keimigrasian yang lebih bersifat "nasional" yang menggantikan seluruh peraturan perundangundangan keimigrasian masa kolonial yang pada masa itu masih berlaku berdasarkan Pasal II Aturan Peralihan UUD 1945. ${ }^{32}$ Sebagaimana ditegaskan M. Iman Santoso,

“....undang-undang ini dirancang dengan jiwa dan semangat yang berbeda dari waktu ke waktu yang lebih menekankan pada kepentingan nasional dan perlindungan yang lebih besar bagi WNI." ${ }^{33}$

31 M. Iman Santoso, Perspektif Imigrasi dalam Pembangunan..., Op.Cit., hlm. 70.

32 Peraturan perundang-undangan kolonial bidang keimigrasian berlaku pada saat itu, berdasarkan Pasal II Aturan Peralihan UUD 1945 (sebelum perubahan)."

33 M. Iman Santoso, Perspektif Imigrasi dalam Pembangunan...., Loc.Cit., hlm. 70. 
Dari paparan di atas, dibentuknya UU No. 9/1992 tidak sekedar mencerminkan adanya politik hukum keimigrasian yang baru di masanya, melainkan juga dalam kerangka harmonisasi dengan perkembangan peraturan perundang-undangan terkait dengan perluasan wilayah negara serta perlindungan kepentingan nasional sesuai tujuan nasional. ${ }^{34}$

Penggantian UU No. 9/1992 dengan UU No. 6/2011 mencerminkan adanya perkembangan kebutuhan hukum untuk menjawab berbagai tantangan yang dihadapi fungsi keimigrasian Indonesia, walaupun secara filosofis tetap didasarkan pada prinsip kedaulatan negara. ${ }^{35}$ Pembentuk UU No. 6/2011 menyadari ada perubahan konteks hubungan antarabangsa dan wargatiapbangsa sebagai dampak globalisasi, sehingga arah politik hukum yang hendak dicapai UU No. 6/2011, yaitu dalam rangka mengantisipasi dampak positif maupun negatif globalisasi yang sejalan dengan HAM. ${ }^{36}$ Sebelumnya, sebagaimana tercermin dalam konsideran UU No. 9/1992, aspek "meningkatnya lalu lintas orang serta hubungan antar bangsa dan negara", telah diperhitungkan dalam pembentukan undang-undang tersebut.

Namun demikian, fenomena globalisasi saat ini, khususnya globalisasi ekonomi dalam bentuk pasar bebas, utamanya di tingkat regional, ${ }^{37}$ menyebabkan pening-

34 Paragraf 5 Penjelasan Umum UU No. 9/ 1992.

35 Sebagaimana ditegaskan dalam konsideran huruf a UU No. 6/ 2011, bahwa: “..keimigrasian merupakan bagian dari perwujudan pelaksanaan penegakan kedaulatan atas Wilayah Indonesia....."

36 Konsideran huruf b UU No. 6/ 2011.

37 Lihat Heru Nugroho. "Agenda Aksi Atas Problema Globalisasi Ekonomi” dalam Khudzafiah Dimyati \& Kelik Wardiono (ed). (2001). Problema Globalisasi Perspektif Sosiologis Hukum, Ekonomi, \& Agama, Cetakan Ke-2, Surakarta: Muham- katan intensitas hubungan ekonomi global dan regional yang berpengaruh pada tatanan nasional. ${ }^{38}$ Perkembangan ilmu pengetahuan dan teknologi dengan segala dampak positif maupun negatif, juga mendorong globalisasi di segala bidang termasuk peningkatan pergerakan manusia lintas batas negara dengan berbagai tujuan, termasuk tujuan-tujuan yang bersifat sementara. ${ }^{39}$ Hal tersebut mencerminkan perlunya, sistem keimigrasian (berperspektif) global yang memudahkan gerakan (movement) orang dari satu negara ke negara lain, baik untuk mendapatkan manfaat yang besar untuk kepentingan nasional maupun untuk menanggulangi dampak negatif dari globalisasi. Dalam hal ini, tercermin bahwa politik hukum dalam UU No.6 Tahun 2011 diarahkan untuk menjawab tantangan tersebut.

Pemaparan di atas membuktikan tesis dari Krasner yang menegaskan bahwa globalisasi tidak secara keseluruhan mengikis kedaulatan negara, walaupun mempengaruhi aspek-aspek tertentu dari kedaulatan negara, yaitu kedaulatan interdependen berupa pengendalian negara terhadap pergerakan lintas batas negara. ${ }^{40}$ Arah politik hukum yang ditegaskan dalam UU No. 6/2011 mencerminkan bahwa aspek kedualatan interdependen diwujudkan dengan tujuan mengelola peluang (dampak menguntungkan) dan mengantisipasi ancaman (dampak merugikan) dari globalisasi.

Beberapa dampak globalisasi yang bersifat menguntungkan, misalnya di bidang

madiyah University Press - Universitas Muhammadiyah Surakarta, hlm. 44.

38 Lihat Bagir Manan. "Hukum Keimigrasian...., Op.Cit., hlm. 12.

39 Ibid., hlm. 11- 12.

40 Stephen D. Krasner, Op..Cit., hlm. 9. 
perekonomian, terkait dengan keberadaan investor asing dengan mengatur kemudahan di bidang keimigrasian (aspek pelayanan), khususnya dalam pemberian izin tinggal tetap. $^{41}$ Sementara itu, dampak negatif globalisasi yang disadari pembentuk UU No. 6/2011, terkait peningkatan intensitas kejahatan internasional atau tindak pidana transnasional, yang dijawab dengan upaya penyelarasan atau harmonisasi tindakan atau ancaman pidana terhadap para pelaku sindikat yang mengorganisasi perdagangan orang dan penyelundupan manusia. ${ }^{42}$ Bahkan dalam konteks tersebut, pembentuk UU No. 6/2011 juga menguatkan aspek penegakan tindak pidana keimigrasian dengan memberikan memberikan kewenangan eksklusif kepada Pejabat Penyidik Pegawai Negeri Sipil (PPNS) Keimigrasian untuk melakukan penyidikan tindak pidana keimigrasian ${ }^{43}$ dan memberikan kualifikasi khusus bagi tindak pidana tersebut sebagai "tindak pidana khusus, sehingga hukum formal dan hukum materiilnya berbeda dengan hukum pidana umum, misalnya adanya pidana minimum khusus." $" 44$

Sementara itu, aspek penghormatan, pelindungan, dan pemajuan hak asasi manusia dalam UU No. 6/2011 dijadikan sebagai bagian integral dari fenomena globalisasi sekaligus sebagai hasil dari tuntutan reformasi di segala bidang. ${ }^{45}$ Hal tersebut mencerminkan adanya pergeseran arah politik hukum keimigrasian Indonesia dari UU No. 9/1992 ke UU No. 6/2011. Di satu sisi, per-

\footnotetext{
41 Paragraf 3 Penjelasan Umum UU No. 6/ 2011.

42 Paragraf 12 huruf h Penjelasan Umum UU No. 6/ 2011.

43 Pasal 47 ayat (1) UU No. 9/ 1992.

44 Paragraf 6 Penjelasan Umum UU No. 6/ 2011.

45 Paragraf 2 Penjelasan Umum UU No. 6/ 2011.
}

kembangan globalisasi menyebabkan arah politik hukum keimigrasian dalam UU No. 6/2011 lebih memberikan kemudahan pergerakan orang asing untuk masuk dengan mengedepankan aspek pelayanan. Namun demikian, di sisi lain, arah politik hukum UU No. 6/2011 juga memperketat aspek pengawasan orang asing, dengan lebih mengedepankan aspek pengawasan represif, terutama dengan penegakan hukum pidana keimigrasian. Hal-hal tersebut diarahkan dengan tetap sejalan dengan nilai-nilai dan norma-norma HAM yang diakui secara universal.

Selain hal-hal di atas, UU No. 6/2011 juga diarahkan untuk menjawab perubahan sistem kewarganegaraan Republik Indonesia berdasarkan UU No. 12 Tahun 2006 tentang Kewarganegaraan Republik Indonesia berkaitan dengan pelaksanaan Fungsi Keimigrasian, antara lain mengenai berkewarganegaraan ganda terbatas ${ }^{46}$ dan pewarganegaraan melalui pernyataan karena perkawinan campuran baik bagi laki-laki maupun perempuan asing yang kawin dengan WNI. ${ }^{47}$

\section{Perkembangan substansi hukum keimigra-} sian

Dari segi substansi hukum keimigrasian, ada beberapa perkembangan prinsip politik hukum keimigrasian dari UU No. 9/1992 ke UU No. 6/2011. Kedua undang-undang

46 Paragraf 12 huruf f Penjelasan Umum UU No. 6/ 2011.

47 Pasal 19 UU No. 12 Tahun 2006. Sebelumnya, berdasarkan UU No.62/1958, hanya perempuan WNA yang melakukan perkawainan campuran saja yang berhak atas kewarganegaraan Indonesia melalui pernyataan. Hal inilah yang oleh banyak pihak dipandang bersifat diskriminatif. Lihat Susi Dwi Harijanti, Rahayu Prasetianingsih, Bilal Dewansyah. (2007). Politik Hukum Kewarganegaraan Indonesia, Laporan Akhir Penelitian, Bandung: Fakultas Hukum Unpad, hlm. 127. 
menganut prinsip selective policy ${ }^{48}$ dalam hal masuk dan keluarnya orang dari dan ke wilayah Indonesia didasarkan pada aspek manfaat terhadap kepentingan nasional ${ }^{49}$, yang sejalan dengan pandangan bahwa kontrol negara atas nama kedaulatan untuk menerima atau menolak masuknya orang asing secara filosofis didasarkan upaya memenuhi kewajiban kepada warga negara. ${ }^{50}$

Namun demikian, ada perbedaan dari segi penekanan dimana selective policy dalam UU No. 9/ 1992 lebih dilekatkan pada prinsip keamanan nasional ${ }^{51}$, sementara dalam UU No. 6/ 2011, prinsip tersebut dilekatkan dengan prinsip hak asasi manusia. ${ }^{52}$ Hal tersebut menunjukkan bahwa pembentuk UU No. 6/ 2011 menginginkan adanya

48 Menurut Bagir Manan, prinsip kebijakan selekif pada dasarnya, menganggap bahwa fasilitas keimigrasian terhadap orang asing hendaknya dengan sungguh-sungguh memperhatikan kemanfaatannya bagi usaha-usaha pembangunan dan usaha mewujudkan kesejahteraan bagi bangsa Indonesia. Bagir Manan. (1996). "Memantapkan Peranan Imigrasi Dalam Pelayanan, Penerapan dan Penegakkan Hukum Keimigrasian Pada Era Globalisasi”, makalah, disampaikan pada Rapat Kerja Direktorat Jenderal Imigrasi, Departemen Kehakiman, Jakarta, 21 Agustus, hlm. 8.

49 Penjelasan Umum paragraf 5 UU No. 9/ 1992 bandingkan dengan Penjelasan Umum Paragraf 9 UU No. 6/ 2011

50 Kristen Walkers, sebagaimana dikutip Satvinder Singh Juss. (2006). International Migration and Global Justice, England-USA: Ashgate Publishing Limited-Ashgate Publishing Company, hlm. 200.

51 Sebagai contoh: orang asing atau bahkan WNI dapat ditangkal untuk masuk karena alasan "bersikap bermusuhan terhadap Pemerintah Indonesia, atau melakukan perbuatan yang mencemarkan nama baik bangsa dan Negara Indonesia" atau "menganggu jalannya pembangunan, jalannya pembangunan, menimbulkan perpecahan bangsa, atau dapat menganggu stabilitas nasional." asal 17 huruf b dan Pasal 18 huruf b UU No. 9/ 1992.

52 Dalam kalimat pertama Penjelasan Umum paragraf 9 UU No. 6/ 2011, prinsip ini ditegaskan sebagai: "kebijakan selektif (selective policy) yang menjunjung nilai-nilai hak asasi manusia (HAM)" keseimbangan antara prinsip kebijakan selektif dengan prinsip HAM. Selain penghapusan penangkalan terhadap $\mathrm{WNI}^{53}$, UU No. 6/ 2011 dalam beberapa hal mengkoreksi atau mengatur kembali berbagai ketentuan yang sebelumnya belum sejalan atau belum mengakomodasi dengan nilai-nilai HAM pada umumnya, misalnya dalam hal perlindungan terhadap korban penyelundupan manusia dan perdagangan orang ${ }^{54}$, pengaturan jangka waktu detensi ${ }^{55}$, maupun hak atas pekerjaan bagi orang asing tertentu yang berada di Indonesia. ${ }^{56}$

Selain itu, ada pula pergeseran dalam hal prinsip Indonesia sebagai non-immigrat state, khususnya dalam hal perubahan pengaturan pranata izin tinggal. Adanya status penduduk tetap yang diperoleh secara langsung tanpa memperhitungkan masa tinggal di Indonesia ${ }^{57}$ serta jangka waktu tidak terbatas untuk izin tinggal tetap bagi

53 Lihat Pasal 1 angka 29 UU N. 6 Tahun 2011. Walaupun secara normatif ketentuan tentang penangkalan terhadap WNI terdapat dalam UU No. 9 Tahun 1992, namun sejak Reformasi 1998 penangkalan terhadap WNI tidak lagi diterapkan. Lihat, Bilal Dewansyah.(2013). Pencegahan dan Penangkalan dalam Perspektif Hak Atas Kebebasan Bergerak Setelah Perubahan UUD 1945, tesis, Bandung : Program Magister Ilmu Hukum FH Unpad, hlm. 163.

54 Pasal 87 ayat (1) dan (2), Pasal 86, Pasal 88, Pasal 136 ayat (3) UU No. 6/ 2011.

55 Perlindungan HAM terhadap deteni antara lain tercermin dari batas waktu deteni diizinkan untuk berada di luar Rumah Detensi Imigrasi (setelah 10 tahun). Lihat Pasal 85 ayat (3) UU No. 6/ 2011.

56 Pasal 61 UU No. 6/ 2011.

57 Berlaku bagi suami, istri, dan/atau anak dari Orang Asing pemegang Izin Tinggal Tetap, orang asing eks WNI dan eks subjek anak berkewarganegaraan ganda RI. Lihat Pasal 54 ayat (1) huruf c, d dan Pasal 60 ayat (3) UU No. 6/ 2011. Sebelumnya, izin tinggal tetap hanya dapat diberikan melalui prosedur pengalihan izin tinggal terbatas. Lihat Pasal 32, 49 dan Pasal 50 PP No. 32 Tahun 1994 tentang Visa, Izin Masuk dan Izin Keimigrasian. 
orang asing tertentu ${ }^{58}$, dapat dipersamakan status permanent resident (penduduk tetap) atau resident aliens (penduduk orang asing) di negara-negara imigran (immigrant states), seperti Amerika Serikat misalnya melalui kebijakan green card lottery. ${ }^{59}$

Dalam hal ini, perubahan pranata izin tinggal, khususnya izin tinggal tetap, mempengaruhi prinsip Indonesia sebagai nonimmigrant state ${ }^{60}$, yang seharusnya berbeda dengan negara-negara imigran yang sebagian besar penduduknya berasal dari masyarakat asli bukan masyarakat pendatang seperti pada negara imigran (immigrant states), semisal Australia, Kanada dan Amerika Serikat yang sebagian besar warga negaranya lebih banyak berasal wilayah negara lain dibandingkan masyarakat asli. ${ }^{61}$

58 Lihat Pasal 59 ayat (1) UU No. 6/ 2011. Sebelumnya, berdasarkan PP No. 32 Tahun 1994 hanya berjangka waktu 5 tahun. Walaupun izin tinggal tetap dapat diperpanjang setiap 5 tahun sekali, namun pada dasarnya pemerintah Indonesia dapat menolak permintaan perpanjangan tersebut, sepanjang syarat-syaratnya tidak terpenuhi. Lihat Pasal 38 ayat (1) PP No. 32 Tahun 1994.

59 Kebijakan green card lottery diperkenalkan pada tahun 1990-an di Amerika Serikat. Pada dasarnya, kebijakan tersebut mengalokasikan sejumlah visa kepada orang-orang dari berbagai kebangsaan yang secara tradisional tidak terwakili dalam kelompok immigran. Secara umum, penduduk tetap di Amerika Serikat harus memiliki visa imigran yang terbagi menjadi 3 kualifikasi, yaitu visa imigran dengan sponsor keluarga, visa imigran dengan sponsor untuk bekerja. Kebijakan green card lottery biasanya diutamakan untuk para pengungsi dan pencari suaka dengan jumlah terbesar berasal dari Kuba. Lihat Alan Allport, John E. Ferguson Jr. (2009). Immigration Policy, $2^{\text {nd }}$ Edition, New York: Chelsea House Publishers, hlm. 20 -21.

60 Menurut Bagir Manan, prinsip Indonesia sebagai non-immigrant state juga merupakan prinsip atau dasar politik hukum keimigrasian Indonesia. Lihat Bagir Manan. "Memantapkan Peranan Imigrasi.....", Op.Cit., hlm. 2.

61 Lihat James P. Lynch, Rita J. Simon. (2003). Immigration The World Over Statutes, Policies, And Practices, Lanham: Rowman \& Littlefield Publishers.Inc, hlm. 3.
Perubahan di atas, apabila dilihat dari prinsip imigrasi sebagai fasilitator pembangunan kesejahteraan masyarakat, akan berdampak pada beban negara untuk meningkatkan kesejateraan rakyat Indonesia, seiring dengan prediksi meningkatnya orang asing yang menetap di Indonesia sebagai penduduk. Di sisi lain, prinsip kebijakan selektif berdasarkan UU No. 6/2011 dalam hal tertentu lebih ketat dibandingkan dalam UU No. 9/1992, terutama dalam hal prosedur masuk dan keluarnya orang dari wilayah Indonesia maupun keberadaan orang asing di Indonesia.

Pengaturan mengenai area imigrasi ${ }^{62}$ di setiap tempat pemeriksaan keimigrasian, misalnya, memungkinkan berjalannya pemeriksaan keimigrasian yang ketat untuk mencegah atau menanggulangi berbagai tindakan pelanggaran keimigrasian. Selain itu, UU No. 6/2011 juga mengatur secara tegas alasan-alasan penolakan permohonan visa $^{63}$, dibandingkan dengan UU No. 9/1992 yang memberikan kriteria umum dalam hal pemberian visa sebagaimana dikemukakan sebelumnya. Adanya alasan-alasan penolakan permohonan visa secara tegas dalam UU No. 6/2011 lebih menjamin kepastian hukum terutama bagi pemohon, dibandingkan pada UU No. 9/1992 yang lebih banyak menyerahkan alasan substanstif penolakan visa melalui peraturan pelaksana. ${ }^{64}$

Dalam hal keberadaan orang asing di Indonesia, ketatnya pengaturan pengawasan orang asing di Indonesia juga tercermin dalam UU No. 6/2011, misalnya kewajiban

62 Pasal 22 ayat (1) dan (2).

63 Pasal 42 UU No. 6/ 2011.

64 Ketentuan lebih lanjut tentang visa berdasarkan UU No. 9/ 1992 diatur dalam PP No. 32 Tahun 2002. 
bagi orang asing tertentu untuk memiliki penjamin. ${ }^{65}$ Penjamin tersebut bertanggung jawab atas keberadaan dan kegiatan orang asing yang dijamin selama tinggal di wilayah Indonesia serta berkewajiban melaporkan setiap perubahan status sipil, status Keimigrasian, dan perubahan alamat. ${ }^{66}$ Dalam hal ini, UU No. 6/2011 menempatkan penjamin orang asing dalam kerangka pengawasan administratif yang sebelumnya, dalam UU No. 9/ 1992 tidak dikenal.

Perwujudan prinsip kebijakan selektif lainnya dalam UU No. 6/2011 juga terlihat pengaturan alasan penolakan orang asing untuk masuk ke wilayah Indonesia yang diperluas, karena alasan terlibat dalam sindikat kejahatan internasional dan tindak pidana transnasional. ${ }^{67}$ Perhatian terhadap upaya pencegahan dan pemberantasan sindikat kejahatan internasional dan tindak pidana transnasional, juga diwujudkan dalam bentuk kriminalisasi tindakan penyelundupan manusia, dengan mengakomodasi ancaman pidana minumum. ${ }^{68}$

Ketentuan sanksi pidana keimigrasian secara umum, selain perubahan kualifikasi tindak pidana keimigrasian sebagai tindak pidana khusus sebagaimana dikemukakan sebelumnya dalam hal arah politik hukum keimigrasian, juga diperkuat dengan memperluas subjek pelaku tindak pidana keimigrasian, sehingga mencakup tidak hanya orang perseorangan tetapi juga korporasi ${ }^{69}$

\footnotetext{
65 Pasal 63 ayat (1) UU No. 6/ 2011.

66 Pasal 63 ayat (2) UU No. 6/ 2011.

67 Pasal 13 ayat (1) huruf g UU No. 6/ 2011. Sebelumnya dalam UU No. 9/ 1992, alasan tersebut tidak ditegaskan sebagai alasan penolakan oleh pejabat imigrasi.

68 Pasal 120 ayat (1) UU No. 6/ 2011.

69 Pasal 136 UU 6 Tahun 2011.
}

serta penjamin terkait dengan kebenaran data orang asing yang dijamin oleh yang bersang$\operatorname{kutan}^{70}$, ancaman sanksi pidana yang lebih berat $^{71}$, serta perluasan tindak pidana yang diancam kepada pejabat imigrasi atau pejabat lain. ${ }^{72}$ UU No. 6/2011 juga mengantisipasi kemungkinan terjadi penyalahgunaan kemudahaan keimigrasian dengan ancaman pidana, misalnya orang asing yang melakukan perkawinan semu (shame marriage) dengan WNI untuk tujuan untuk memperoleh Dokumen Keimigrasian atau status kewarganegaraan. ${ }^{73}$

Adanya perubahan prinsip keamanan dalam UU No. 6/2011 yang lebih menitikberatkan pada aspek penegakan hukum baik melalui penegakan hukum administratif maupun pidana, dibandingkan alasan-alasan keamanan yang subjektif sebagaimana dalam UU No. 9/1992, mencerminkan bahwa prinsip keimigrasian di bidang keamanan nasional dalam UU No. 6/2011 lebih ketat namun dengan kriteria yang lebih objektif yaitu terkait dengan aspek penegakan hukum administrasi dan pidana keimigrasian, dibandingkan dengan UU No. 9/1992. Hal ini mencerminkan perubahan hubungan antara fungsi keimigrasian di bidang keamanan dan penegakan hukum. Paradigma lama memisahkan antara fungsi keamanan negara dan penegakan hukum, namun dalam per-

\footnotetext{
70 Pasal 118 UU No. 6/ 2011.

71 Pembaratan ancamana pidana, yaitu dalam pidana denda (hingga mencapai 500 juta rupiah). Misal Pasal 118 UU No. 6/ 2011. Sementara itu sebelumnya dalam UU No. 9/ 1992 ancaman pidana denda paling tinggi hanya 30 juta rupiah (Pasal 49 dan Pasal 56).

72 Bandingkan Pasal 59 UU No. 9/ 1992 dengan Pasal 132 - 133 UU No. 6/ 2011.

73 Tindak pidana tersebut diancam pidana paling tinggi 5 tahun dan denda paling banyak 500 juta rupiah. Lihat Pasal 135 UU No. 6/ 2011.
} 
kembangannya, fungsi keamanan negara tidak terpisah dari fungsi penegakan hukum. Bahkan fungsi keamanan negara diwujudkan fungsi penegakan hukum. ${ }^{74}$

\section{Perkembangan bentuk dan jangkauan hukum keimigrasian}

Dari segi bentuk atau jenis pengaturan, politik hukum keimigrasian diwadahi terutama dalam undang-undang, yaitu UU No. 9/1992 yang kemudian digantikan dengan UU No. 6/2011. Pembentuk UU No. 6/2011 menyadari bahwa pembaharuan hukum keimigrasian, tidak dapat dilakukan hanya dengan melakukan perubahan parsial, melainkan perubahan komprehensif melalui penggantian undang-undang keimigrasian. ${ }^{75}$

Dari segi jangkuan pengaturan, hal tersebut mencerminkan bahwa UU No. 6/ 2011 tidak hanya menjangkau hukum yang berlaku saat ini (ius constitutum) melainkan juga ius constituendum. Sebagian besar ketentuan dalam UU No. 6/2011 terkait dengan ius constitutum, dengan memperbarui berbagai pranata hukum keimigrasian yang telah ada dalam UU No. 9/1992, seperti prosedur ke luar masuk wilayah Indonesia, pencegahan dan penangkalan, detensi imigrasi, visa, surat perjalanan Republik Indonesia, izin tinggal, berbagai dokumen keimigrasian, serta ketentuan pidana keimigrasian pada umumnya.

Namun demikian, terdapat beberapa pranata hukum baru yang diatur dalam UU No. 6/2011, yaitu mengenai kriminalisasi

74 Bandingkan dengan M. Iman Santoso, Perspektif Imigrasi dalam Pembangunan...., Op.Cit., hlm. 24.

75 Paragraf terakhir Penjelasan Umum UU No. 6/ 2011. tindak pidana penyelundupan manusia, perlindungan terhadap korban tindak pidana penyelundupan manusia dan perdagangan orang sebagai upaya penyesuaian terhadap konvensi internasional yang telah diratifi$\mathrm{kasi}^{76}$, serta pendidikan khusus keimigrasian dan pencegahan oleh pejabat lainnya yang ditentukan oleh undang-undang lain di kemudian hari, dan mekanisme keberatan atas keputusan pencegahan. ${ }^{77}$

Ius constituendum juga tercermin dari berbagai delegasi pada peraturan pelaksana. Baik UU No. 9/1992 maupun UU No. 6/2011 memerintahkan pengaturan lebih lanjut berbagai kaidah dalam kedua undang-undang tersebut dalam peraturan pelaksana. lebih Perbedaannya, UU No. 6/2011 lebih rinci mengatur kaidah-kaidah hukum keimigrasian dibandingkan UU No. 9/1992 yang tercermin dari banyaknya pasal dan bab yang diatur ${ }^{78}$, sehingga mempengaruhi materi yang diatur dalam peraturan pelaksana. Rinci atau tidaknya materi suatu undangundang akan mempengaruhi pelaksanaan undang-undang tersebut. Suatu undang-undang yang sangat rinci terkait dengan kepentingan orang banyak, agar pelaksanaannya sejalan dengan perlindungan HAM. Namun menurut Bagir Manan, kadang-kadang ada pula kemungkinan suatu objek yang akan

76 UNCTOC (2000) yang diratifikasi dengan UU No. 5 Tahun 2009, dan protokal opsional dari konvensi tersebut yang berkaitan dengan penyelundupan manusia, yaitu Protocol Against The Smuggling Of Migrants By Land, Sea And Air, Supplementing The United Nations Convention Against Transnational Organized Crime dengan UU No. 15 Tahun 2009.

77 Pasal 96 ayat (1), Pasal 140 UU No. 6/ 2011.

78 Dilihat dari jumlah pasal dan bab, UU No. 6/ 2011 terdiri dari 145 pasal dan 15 bab, lebih banyak dibandingkan dengan UU No. 9/ 1992 yang terdiri dari 68 pasal dan 11 bab. 
diatur mempunyai sifat yang sangat dinamis, sehingga perlu diubah atau disesuaikan dari waktu ke waktu, kalau harus diatur dengan undang-undang mungkin akan menjadi hambatan karena membentuk undang-undang membutuhkan tata cara tertentu yang memerlukan waktu. ${ }^{79}$ Dalam hal ini, dapat dikatakan bahwa materi suatu undang-undang idealnya tidak terlalu rinci namun tidak terlalu pendek dengan tolak ukur agar dapat menjamin kepastian hukum kepentingan pihak yang diatur dan dapat menyesuaikan dengan perkembangan zaman.

Pengaturan yang tidak terlalu rinci dalam menyebabkan UU No. 9/1992 dapat bertahan sampai dengan 20 tahun, dengan hanya perubahan sebanyak 1 kali mengenai penghapusan paspor haji. ${ }^{80}$ Perubahan justru terjadi sangat dinamis pada level peraturan pelaksana dalam rangka menyesuaikan dengan perkembangan kebutuhan masyarakat. ${ }^{81}$ Hal tersebut sejalan dengan karakter hukum keimigrasian yang merupakan bagian dari hukum administrasi khusus yang berkembang dinamis. ${ }^{82}$

Namun demikian, ketentuan-ketentuan dalam UU No. 9/1992 yang tidak terlalu rinci, dibandingkan UU No. 6/2011, menyebabkan pengaturan lebih lanjut menjadi materi dalam peraturan pelaksana, terutama

79 Bagir Manan. (1992). Dasar-Dasar Perundangundangan Indonesia, Jakarta: Ind-Hill.Co, hlm. 41.

80 Melalui Peraturan Pemerintah Pengganti UndangUndang (Perpu) No. 3 Tahun 2009 (ditetapkan menjadi undang-undang dengan UU No. 37 Tahun 2009).

81 PP No. 32 Tahun 1994, misalnya telah diubah 2 kali sejak pembentuknnya, yaitu dengan PP No. 18 Tahun 2005 dan terakhir dengan PP No. 38 Tahun 2005.

82 Bagir Manan. "Hukum Keimigrasian...", Loc. Cit., hlm. 8. peraturan pemerintah. ${ }^{83}$ Di sisi lain, hal tersebut menyebabkan berbagai hal substantif diserahkan pada peraturan pelaksana, misalnya dalam hal alasan penolakan Visa tidak atur secara spesifik, namun hanya diatur bahwa "Visa diberikan kepada orang asing yang maksud dan tujuan kedatangannya di Indonesia bermanfaat serta tidak akan menimbulkan gangguan terhadap ketertiban dan keamanan nasional." ${ }^{84}$

Ketentuan lebih lanjut mengenai visa diatur lebih lanjut dalam peraturan pemerintah, sehingga alasan-alasan penolakan visa diserahkan pada peraturan eksekutif untuk diatur. Bahkan penolakan visa dalam PP No. 32 Tahun 1994 sebagai peraturan pelaksana UU No. 9/ 1992 diserahkan pada Menteri dan Kepala Perwakilan RI di luar negeri tanpa adanya ketentuan mengenai alasan-alasan penolakan visa. ${ }^{85}$ Atau dengan kata lain meminjam istilah tim Pusat Studi Kebijakan Hukum (PSHK), penolakan visa didasarkan pada diskresi pejabat pemerintahan. ${ }^{86}$

Sementara itu, dalam UU No. 6/2011 diatur alasan spesifik alasan-alasan penolakan visa secara rinci. ${ }^{87}$ Hal tersebut lebih menjamin kepastian baik bagi orang asing maupun pejabat imigrasi yang akan memproses permohonan visa. Namun demikian, pengaturan yang lebih rinci juga dapat menyebabkan ketertinggalan daya laku suatu

83 Lihat ketentuan delegasi pada peraturan pelaksana dalam Pasal 7 ayat (2), Pasal 17 huruf f, Pasal 23, Pasal 28, Pasal 37, Pasal 46, Pasal 66 UU No. 9/ 1992.

84 Pasal 6 ayat (2).

$85 \quad$ Pasal 7 - Pasal 9 PP No. 32 Tahun 2004.

86 Fajri Nusyamsi, dkk. (2012). Catatan Kinerja DPR 2011, Legislasi: Aspirasi atau Transaksi?, Jakarta: PSHK, hlm. 74.

87 Diatur dalam Pasal 42 UU No. 6/ 2011. 
undang-undang dalam masyarakat. Dalam hal visa misalnya, dapat saja terjadi suatu tindakan merupakan alasan yang logis untuk menolak permohonan visa, namun tidak diatur dalam UU No. 6/2011, apalagi undangundang tersebut tidak membuka adanya kemungkinan alasan penolakan visa lainnya selain yang ditentukan dalam undangundang tersebut. Hal ini menimbulkan kekhawatiran mengenai keberlakuan UU No. 6/2011 di kemudian hari.

Namun demikian, rincinya pengaturan dalam UU No. 6/2011 tidak terlepas dari salah satu karakter undang-undang tersebut yang bermaksud mewujudkan keinginan ketegasan terhadap kewenangan (pemerintah) dan hak dari warga negara maupun orang asing terkait dengan keimigrasian. ${ }^{88} \mathrm{Hal}$ tersebut juga sejalan prinsip yang mengakomodasi nilai-nilai HAM dalam urusan keimigrasian, walauapun dalam hal tertentu, ketentuan yang bersentuhan HAM, justru tidak diatur rinci dalam UU No. 6/2011, misalnya dalam hal alasan pencabutan paspor yang diserahkan sepenuhnya untuk diatur dalam peraturan pemerintah. ${ }^{89} \mathrm{Hal}$ ini menunjukkan jangkauan pengaturan yang begitu rinci dalam UU No. 6/2011 tidak selalu konsisten dalam pengaturannya.

UU No. 6/2011 walaupun mengatur lebih rinci kaidah-kaidah hukum keimigrasian dibandingkan dengan UU No. 9/1992, tetap memerintahkan sejumlah ketentuan untuk diatur dalam pelaksana, terutama peraturan pemerintah dan peraturan menteri. Rincinya pengaturan dalam UU No. 6/2011 juga mengantisipasi dampak keterlambatan

$88 \quad$ Fajri Nursyamsi, dkk, Op.Cit, hlm. 73.

89 Pasal 32 ayat (1) dan Pasal 33 UU No. 6/ 2011. pembentuk peraturan pelaksana yang seringkali menghambat pelaksanaan suatu undangundang. ${ }^{90}$

Harapannya, peraturan pelaksana dari UU No. 6/2011 tidak lebih banyak mengatur hal-hal substantif dibandingkan pada masa undang-undang sebelumnya. Hal ini tercermin dari pengaturan PP No. 31 Tahun 2013 tentang Peraturan Pelaksanaan UU No. 6/2011 yang secara umum tidak mengatur substansi politik hukum, namun lebih bersifat prosedural. Namun demikian, salah satu kelemahan PP No. 31 Tahun 2013 yaitu tidak mengatur mekanisme pengajuan keberatan, khususnya dalam hal pencegahan. Padahal mekanisme keberatan dalam konteks pencegahan ke luar negeri merupakan hal baru ${ }^{91}$ dan UU No. 6/ 2011 telah mendelegasikan ketentuan lebih lanjut tentang pencegahan dan penangkalan diatur dengan peraturan pemerintah. ${ }^{92}$ Ketiadaan ketentuan mekanisme pengajuan dan tindak lanjut keberatan atas keputusan pencegahan, dikhawatirkan menjadi pranata ini menjadi tidak terakses oleh publik.

Kebutuhan Hukum Keimigrasian Indonesia dan Politik Hukum Keimigrasian Indonesia dalam Undang-Undang No. 6 Tahun 2011

Kebutuhan hukum keimigrasian yang dimaksud dalam tulisan ini adalah persoalan keimigrasian yang dihadapi Indonesia yang

90 UU No. 6/ 2011 memerintahkan pembentuk peraturan pelaksana undang-undang tersebut paling lama 1 tahun setelah diundangkan (lihat Pasal 144). Undang-undang tersebut diundangkan pada tanggal 5 Mei 2011, namun hingga saat ini belum ada satu pun peraturan pelaksana yang telah ditetapkan.

$91 \quad$ Pasal 96 ayat (1) UU No. 6/ 2011.

92 Pasal 103 UU No. 6/ 2011. 
membutuhkan pengaturan melalui instrumen hukum keimigrasian. Setidaknya ada 3 persoalan keimigrasian pokok yang terjadi dalam praktik, yaitu masalah imigran ilegal, penyelundupan manusia, serta masalah pencari suaka dan pengungsi.

Terkait masalah imigran ilegal, terjadi peningkatan yang signifikan dalam beberapa tahun terakhir. Berdasarkan data International Organization for Migration (IOM), sejak Desember 1999 sampai dengan 30 April 2010, jumlah imgran ilegal yang ditangani IOM sebanyak 7.917 orang, imigran yang pulang secara sukarela ke negara asalnya 1.508 orang, imigran yang dititipkan ke negara ketiga 1.432 orang, imigran dalam pengawasan IOM 1.255, serta imigran lainnya 3.772 orang. ${ }^{93}$ Jumlah tersebut meningkat dimana rata-rata tiap tahun hingga tahun 2011, terdapat lebih dari 10.000 imigran ilegal, dan meningkat kembali, per 31 Agustus 2013 mencapai 11.132 kasus. Kasus ini terdiri atas 8.872 pencari suaka dan 2.260 pengungsi ${ }^{94}$, yang sebagian besar masuk melalui perairan Indonesia. ${ }^{95}$ Dalam hal ini, imigran ilegal yang sebagian besar masuk

93 Asep Kurnia. (2011). IImigran Ilegal Potret Penanganan dan Pencegatan dalam Perspektif Sistem Manajemen Nasional, Jakarta: IOM, hlm. 3.

94 Pernyataan Denis Nihil Chief on Mission IOM. Republika.co.id. (2003), "10.593 Kasus Imigran Ilegal Masuk Perairan Indonesia", tersedia dari http://www.republika.co.id/berita/nasional/jawatengah-diy-nasional/13/11/06/mvuci6-10593kasus-imigran-ilegal-masuk-perairan-indonesia. [Diakses 23 November 2013].

95 Sebagaimana dikatakan Brigjen Pol. M. Ghufron, Kepala Biro Bin Opsnal Baharkam Polri, dalam sosialisasi penyelundupan manusia di Yogyakarta yang digelar IOM dan Polri, Rabu 6 november 2013, data di kepolisian RI hingga Oktober 2013 ini sedikitnya ada 10.593 kasus imigrasi ilegal yang masuk ke Indonesia melalui perairan (lautan). Ibid. secara berkelompok, bermaksud mencari suaka dengan menjadikan Indonesia sebagai tempat tujuan maupun sebagai transit, khususnya menuju Australia. Masuknya imigran ilegal tersebut biasanya juga terkait dengan kasus penyelundupan manusia.

Hal di atas menunjukkan bahwa dalam berpraktik antara imigran ilegal, pencari suaka, pengungsi dan penyelundupan saling berkaitan. Dalam hal ini, imigran illegal atau orang asing yang masuk ke Indonesia secara tidak sah seringkali mengklaim sebagai pencari suaka atau pengungsi. Selain itu, sebagian besar imigran illegal berkaitan dengan kasus penyelundupan manusia, khususnya bagi pihak-pihak yang mengakomodasi masukknya imigran illegal tersebut ke wilayah Indonesia.

Hadirnya imigran ilegal menimbulkan masalah dalam praktik. Ketika para imigran ilegal berinteraksi dan bersosialisasi dengan warga yang tinggal sekitar Rumah detensi, berpotensi menyebarkan pengaruh negatif, minuman keras, pelecehan seksual, perselingkuhan, seks bebas hingga permasalahan hutang-piutang di warung serta tindakan asusila lainnya melawan moral dan etika bangsa Indonesia. ${ }^{96}$ Permasalahan lain timbul saat imigran ilegal yang tertangkap dimasukan kedalam rumah detensi, ${ }^{97}$ tidak sedikit para imigran ilegal yang berhasil kabur dari Rumah detensi dan kantor imigrasi. Selama bulan Mei 2013, sebanyak 29 imigran kabur dari Rumah detensi Medan. Di bulan Juli 2013, sejumlah puluhan imi-

96 Idem.

97 Indonesia menyediakan tempat penampungan untuk mereka yakni Rumah Detensi Imigrasi (Rudenim), Indonesia juga menyediakan akomodasi, fasilitas, makanan dan minuman untuk mereka. 
gran pun berhasil lolos dari Kantor Imigrasi Malang, 98 imigran kabur dari Kantor Imgirasi Madiun, 120 imigran melarikan diri dari Kantor Imigrasi Blitar, 42 imigran kabur dari Kantor Imigrasi Cilacap. Mereka kabur dengan berbagai cara dari menjebol dinding, merusak langit-langit dan atap, menggergaji jeruji teralis, bahkan hingga mengelabui petugas. ${ }^{98}$

Di sisi lain, keberadaan mereka sangat memprihatinkan, dari laki-laki, perempuan, dan anak-anak ditempatkan di satu tempat di Rumah detensi. Padahal, kelebihan kapasitas terjadi di hampir semua Rumah detensi di Indonesia, seperti Rumah detensi Medan, Rumah detensi Pekanbaru, Rumah detensi Tanjung Pinang, dan Rumah detensi lainnya. Akibatnya, kericuhan antardeteni pun terjadi di Rumah detensi, baik masalah SARA maupun masalah fasilitas (sel yang tak mampu lagi menampung mereka). ${ }^{99}$ Artinya, keberadaa imigran ilegal di Indonesia memberikan beban tersendiri bagi Indonesia, baik bagi Pemerintah Pusat, pemerintah daerah maupun masyarakat pada umumnya.

Penyelundupan manusia yang seringkali menjadi modus masuknya imgran ilegal tidak terlepas dari berbagai konflik yang terjadi di berbagai belahan dunia. Hal ini dibuktikan dengan besaran imigran ilegal (misalnya, yang di bawah pengawasan IOM - 2010) yang berasal dari negara-negara yang landa konflik, seperti Afganistan (urutan pertama), Irak (urutan ketiga), Myanmar (uru-

98 Ridwan Arifin. (2013). "Bom Waktu Imigran Gelap di Indonesia", Kompasiana, tersedia dari http://www.kompasiana.com/ridwan-arifinjazz/ bom-waktu-imigran-gelap-di-indonesia 552a8 794f17e617e17d62438. [Diakses 29 November 2013].

99 Ibid. tan keempat), dan Iran (urutan kelima). ${ }^{100}$ Gelombang migrasi ilegal tersebut menjadikan penyelundupan manusia menjadi semakin masif dan menjadi seuah kegiatan yang teroganisir yang berorientasi profit semata dengan memanfaatkan imigran. ${ }^{101}$ Bahkan dalam perkembangan, menurut IOM, para imigran dikoordinir oleh para smuggler yang semakin hari semakin rapi dalam menjalankan operasinya, misalnya melalui perubahan modus operandi dengan jalan memasuki wilayah Indonesia secara legal dan memanfaatkan ijin wisata (izin kunjungan -pen), sesampainya di Indonesia mereka bertemu dan berkoordinasi dengan para smuggler untuk mempersiapkan penyebrangannya ke negara tujuan. ${ }^{102}$ Dalam hal ini, kasus penyulundupan manusia jauh lebih kompleks dibandingkan dengan persoalan imigran ilegal.

Selain itu, masalah migrasi ilegal menjadi semakin kompleks ketika sebagian dari imigran ilegal menyatakan mencari suaka untuk mendapatkan status pengungsi. Padahal status pernyataan untuk mencari suaka dalam konteks mendapatkan status pengungsi harus didapatkan melalui prosedur khusus dari UNHCR, badan PBB mengurusi masalah pengungsi berdasarkan Konvensi Internasional tentang Pengungsi (1951) dan protokolnya. Namun demikian, tidak semua imigran ilegal pada saat masuk menyatakan diri sebagai pencari suaka. Bagi mereka yang tidak bermaksud mencari suaka, opsi

\footnotetext{
100 Asep Kurnia, Op.Cit., hlm. 4.

101 Lihat IOM. (2012). Petunjuk Penanganan Tindak Pidana Penyulundupan Manusia: Pencegatan, Penyidikan, Penuntutan dan Koordinasi di Indonesia, Jakarta:, IOM Misi Indonesia, hlm. 19. 102 Ibid.
} 
pengembalian ke negara asal secara sukarela menjadi opsi utama, walauapu untuk sementara waktu mereka ditempatkan di Rumah Ditensi Imigrasi atau tempat penampungan lainnya. Sementara itu, bagi mereka yang menuntut hak atas suaka akan dirujuk ke UNHCR Perwakilan Indonesia untuk diproses lebih lanjut dalam waktu yang cukup panjang.

Indonesia sendiri tidak memiliki kerangka hukum dan administratif, serta dengan maksud untuk memastikan akses yang adil dan efisien untuk prosedur suaka bagi mereka yang tiba di Indonesia, UNHCR melakukan pendataan dan penentuan status pengungsi. ${ }^{103}$ Seseorang yang memiliki surat keterangan sebagai pencari suaka atau status pengungsi dari UNHCR, tidak dipermasalahkan izin tinggalnya dan akan dilindungi dari refoulment (pemulangan kembali ke negara dimana mereka memiliki ketakutan dari persekusi). ${ }^{104}$ Dalam praktik, antara tahun 2001 dan 2011, UNHCR telah menempatkan sebanyak 1916 pengungsi ke negara ketiga dan pada tahun 2011, 403 orang telah ditempatkan ke negara ketiga (308 orang ke Australia dan 5 orang ke Kanada). ${ }^{105}$

Persoalannya, keberadaan para pencari suaka dan pengungsi (yang belum mendapatkan negara penempatan) berpotensi menimbulkan masalah. Para pencari suaka dan pengungsi tersebut seperti halnya imigran legal dapat bergerak secara bebas di Indonesia, walaupun sebagian dari mereka masuk ke Indonesia secara ilegal. Mereka sebenarnya diwajibkan mendaftarkan keberadaan tempat tinggal mereka di kantor kepolisian ter-

\footnotetext{
103 Idem., hlm. 187.

104 Ibid.

${ }^{105}$ Idem., hlm. 188.
}

dekat sesegera mungkin ${ }^{106}$, namun tidak menutup kemungkinan mereka tidak melakukan hal tersebut atau bahkan melakukan pelanggaran lainnya, baik hukum maupun adat istiadat setempat. Apabila pencari suaka atau pengungsi yang berada di Indonesia tinduk pada hukum positif Indonesia. Jika mereka melakukan tindak pidana, misalnya ketika dikenakan penahanan, prosedur hukum positif Indonesia-lah yang harus menjadi acuan. ${ }^{107}$ Namun demikian, tidak ada mekanisme preventif dalam hukum Indonesia yang mengatur keberadaan mereka di Indonesia, sehingga rentan terhadap berbagai persoalan di kemudian hari, terkait dengan perilaku mereka dalam kehidupan masyarakat Indonesia. Bahkan status pencari suaka atau pengungsi seringkali dijadikan sebagai salah satu modus operandi penyelundupan manusia.

Dalam modus operandi seperti ini, para imigran masuk ke Indonesia masuk secara sah menggunakan visa on arrival, lalu kemudian sambil menunggu pemberangkatan ke negara tujuan, di tempat yang telah disediakan penyelundup manusia, mereka diminta untuk mengurus sertifikat pengungsi (awalnya berupa keterangan pencari suaka - pen), untuk memperpanjang masa tinggal mereka karena visa on arrival yang berlaku 30 hari dan dapat diperpanjang untuk 30 hari ke depan akan habis masa berlakunya. ${ }^{108}$ Artinya, prosedur mendapatkan suaka sangat rentan dijadikan sebagai modus penyelundupan hukum dalam konteks penyelundupan manusia.

\footnotetext{
${ }^{106}$ Idem., hlm. 190

107 Idem., hlm. 191.

108 Idem., hlm. 65.
} 
Masalah-masalah di atas tidak semua mendapatkan perhatian dalam konteks perkembangan politik keimigrasian Indonesia, khususnya setelah UU No. 9/1992 digantikan dengan UU No. 6/2011. Dalam hal ini, arah perkembangan politik hukum keimigrasian Indonesia pada antisipasi dampak negatif globalisasi, tercermin dalam hal kriminalisasi penyelundupan manusia, dimana terdapat sanksi pidana yang tegas, termasuk apabila pelakunya sebuah korporasi, serta perlindungan terhadap korban penyelundupan manusia sebagaimana dikemukakan sebelumnya. Perhatian terhadap penghapusan tindak pidana penyelundupan manusia juga terlihat dalam hal pengaturan mengenai pencegahan dan penanganan tindak pidana tersebut dalam UU No. 6/ 2011. Dalam hal ini, adanya pengaturan sanksi dan upayaupaya penanganan tindak pidana tersebut, mengakomodasi kebutuhan hukum keimigrasian Indonesia dalam penanganan tindak pidana penyelundupan manusia.

Pada masa penerapan UU No. 9/1992, banyak imigran ilegal yang masuk ke Indonesia dianggap sebagai korban penyelundupan manusia, namun tidak ada sanksi bagi pihak-pihak yang dianggap menyelundupkan imigran ilegal. Para imigran tersebut hanya terjerat pelanggaran izin keimigrasian (Pasal 42) atau tindak pidana keimigrasian biasa sebagaimana diatur dalam Pasal 50 UU No. 9/1992. Sementara itu, di negara lain, seperti Australia, penyelundupan manusia telah lama dikriminalisasi. Hal tersebut pernah menjerat WNI yang juga ikut terlibat (terhasut oleh para penyelundup) dalam penyelundupan manusia. Contohnya adalah kasus Abdul Hamid, warga negara Indone- sia asal Bima, Nusa Tenggara Barat (NTB), yang dikenakan hukuman penjara selama enam tahun oleh Pengadilan Perth, Australia Barat, karena terbukti bersalah menyelundupkan tiga warga Iran dan sembilan warga Afghanistan ke negara itu pada 29 September 2008. ${ }^{109}$ Saat ini, UU No. 6/ 2011 telah memberikan landasan hukum bagi pencegahan dan penanganan tindak pidana penyelundupan manusia.

Penanganan imigran ilegal secara umum, juga telah mendapatkan perhatian yang cukup dalam UU No. 6/2011 melalui pengetatan prosedur masuk ke Indonesia dan pengaturan pengawasan keimigrasian yang lebih detil dibandingkan UU No. 9/1992. Namun demikian, dalam praktik masih menimbulkan persoalan. Tim Pengawasan Orang Asing (PORA) ${ }^{110}$ yang dibentuk Direktorat Jenderal Imigrasi berdasarkan Surat Keputusan Menteri Hukum dan HAM RI Nomor M.HH-01.GR.02.01 Tahun 2013 tentang Tim Pengawasan Orang Asing Tingkat Pusat Tahun Anggaran 2013 pun, ternyata belum mampu menyelesaikan masalah imigran ilegal.

Sebenarnya, persoalan tersebut juga disebabkan karena faktor geografis Indonesia yang dikelilingi perairan (lautan) yang bersifat terbuka, sehingga menjadi pintu ma-

109 Sam Fernando. (2013). "Politik Hukum Pemerintah (Direktorat Jenderal Imigrasi) Dalam Menanggulangi Masalah Penyelundupan Manusia”, hlm.8, tersedia pada http://hukum.ub.ac.id/ wp-content/uploads/2013/04/Jurnal-Sam-Fernando.pdf [diakses pada 23 Maret 2014].

110 Tim tersebut melakukan prioritas penguatan satgas diutamakan pada matra udara dengan pertimbangan bahwa trend pergerakan imigran ilegal telah banyak memanfaatkan jalur udara domestik yang dianggap kurang memperoleh perhatian dari instansi penegak hukum dan instansi terkait lainnya. 
suk potensial bagi imigran ilegal. Imigran ilegal yang datang secara berkelompok, biasanya bermaksud untuk transit di Indonesia untuk menyebrang ke Australia. Wilayah yang paling sering dimanfaatkan sebagai jalur penyebrangan ke Australia adalah di sepanjang pantai selatan Pulau Jawa, yang memiliki kondisi alam yang sulit diprediksi, sehingga aparat keamanan jarang menyentuh wilayah tesebut karena alasan keamanan. ${ }^{111}$

Persoalan tersebut semakin kompleks, karena Indonesia tidak memiliki infrastruktur yang memadai untuk melakukan pemantauan secara rutin dan efektif pada wilayahwilayah perbatasan laut. Di sisi lain, persoalan imigran ilegal juga disebabkan karena kebijakan Pemerintah yang memudahkan masuknya orang asing dari negara-negara asing yang banyak mengirimkan imigran melalui mekanisme visa on arrival, seperti Irak dan Iran. Sebagaimana dikemukakan sebelumnya, sebagian dari para imigran ilegal tersebut pada awalnya menggunakan visa on arrival untuk masuk ke Indonesia, dan sangat mungkin menjadi ilegal, misalnya karena mereka membuang dokumen keimigrasiannya setelah masuk atau karena mereka over stayed atau menggunakan modus secara pencari suaka. Artinya, Pemerintah perlu meninjau ulang negara-negara yang warga negaranya diberikan fasilitas visa saat kedatangan, berdasarkan asas resiprositas.

Persoalan utama ada pada masalah penanganan pencari suaka dan pengungsi. Sebagaimana diketahui, masalah utama pencari suaka dan pengungsi di Indonesia disebabkan karena di satu sisi, UU No. 9/1992 tentang Keimigrasian, tidak (belum) menga-

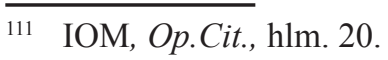

tur bagaimana penanganan terhadap pencari suaka, pemegang status pengungsi yang diakui, dan yang tidak diakui serta bagaimana status keimigrasian mereka selama berada di Indonesia. ${ }^{112}$ Di sisi lain, Indonesia bukan negara pihak Konvensi Pengungsi. Dengan demikian, pada masa UU No. 9/ 1992, terjadi kekosongan pengaturan mengenai pencari suaka dan pengungsi. Persoalan ini, ternyata tidak mendapatkan perhatian dalam pembentukan UU No. 6/ 2011. Padahal adanya dasar hukum penanganan masalah pengungsi, khususnya dalam bentuk undangundang menjadi sangat penting, mengingat persoalan di atas, dan mengingat hak mencari suaka politik merupakan salah satu hak asasi manusia yang dijamin dalam Pasal 28G ayat (2) Perubahan Kedua UUD NRI 1945, sehingga pembatasannya hanya dapat diatur dalam bentuk undang-undang. ${ }^{113}$

\section{PENUTUP}

Pergantian undang-undang keimigrasian dari Undang-Undang No. 9 Tahun 1992 ke Undang-Undang No. 6 Tahun 2011 mencerminkan perkembangan arah, substansi, bentuk dan jangkauan politik hukum keimigrasian Indonesia. Perkembangan arah politik hukum ditekankan untuk lebih dapat menghadapi dampak globalisasi baik dampak positif maupun dampak negatif, selain untuk menyesuaikan dengan perkembangan kemasyarakatan dan kenegaraan Indonesia, kebijakan atau peraturan perundang-undangan terkait, serta bersifat antisipatif terhadap permasalahan di masa depan.

\footnotetext{
112 Ajat Sudrajat Havid (2008) dalam Asep Kurnia, Op.Cit., hlm. 36.

113 Pasal 28J ayat (2) Perubahan Kedua UUD NRI 1945 (2000).
} 
Dari segi substansi, politik hukum keimigrasian saat ini mengubah berbagai prinsip-prinsip hukum keimigrasian sebelumnya, antara lain prinsip kebijakan selektif diimbangi dengan prinsip HAM (walaupun dalam hal tertentu, tidak sejalan dengan prinsip HAM, seperti misalnya jangka waktu pencegahan yang dapat diperpanjang) ${ }^{114}$, prinsip keamanan yang diartikan sebagai penegakan hukum diimbangi dengan prinsip keimigrasian sebagai fasilitator pembangunan (kesejahteraan), serta prinsip Indonesia non-immigrant state yang lebih terbuka. Dari segi bentuk dan jangkauan, politik hukum keimigrasian Indonesia saat ini, lebih banyak mengatur kaidah-kaidah hukum keimigrasian dengan rinci dibandingkan sebelumnya, sehingga ius constituendem yang akan diatur dalam peraturan pelaksana dipastikan tidak banyak mengatur hal-hal substantif, sehingga mengurangi diskresi berlebihan kepada pemerintah. Walaupun demikian, dalam peraturan pelaksananya (PP No. 31/2013), justru terdapat materi yang semestinya diatur dalam PP namun tidak diatur (dalam hal mekanisme pengajuan keberatan atas keputusan pencegahan).

Sebagian dari arah dan substansi politik hukum keimigrasian setelah berlakunya UU No.6/2011 menjawab sebagian kebutuhan hukum keimigrasian Indonesia, seperti untuk kasus penyelundupan manusia, namun persoalan imigran ilegal masih menjadi per-

114 Dalam perkembangannya, ketentuan jangka waktu keputusan pencegahan yang dapat diperpanjang terus (frase "dan setiap kali dapat diperpanjang" dalam Pasal 97 ayat (1) UU No. 6/2011), dibatalkan oleh Mahkamah Konstitusi Putusan No. 64/PUU-IX/2011. LIhat pembahasan lebih lanjut mengenai hal ini dalam Bilal Dewansyah. (2013). Op.Cit., hlm. 182. soalan dalam praktik. Dalam aspek lain, politik hukum dalam UU No.6/2011 sama halnya dengan UU No.9/1992, melupakan kebutuhan hukum keimigrasian selebihnya, karena tidak menyentuh aspek pengaturan penanganan pencari suaka dan pengungsi. Oleh karena itu, penanganan imigran ilegal perlu dititikberatkan pada aspek preventif, terutama dilakukan melalui pengetatan penerimaan orang asing yang masuk serta pengawasan pada perbatasan perairan Indonesia, dengan mendepankan kerjasama dengan negaranegara yang banyak mengirimkan imigran ilegal. Selain itu, Pemerintah perlu meninjau ulang negara-negara yang warga negaranya mendapatkan fasilitas visa saat kedatangan, yang merupakan negara-negara yang banyak mengirimkan imigran - imigran ilegal. Selanjutnya, diperlukan pengaturan khusus, pada level undang-undang yang mengatur tentang mekanisme pemberian dan penanganan pencari suaka. Terakhir, diperlukan penelitian lebih lanjut pada beberapa aspek spesifik hukum keimigrasian dengan masalah-masalah pencari suaka, pengungsi dan imigran ilegal secara umum.

\section{BIBLIOGRAFI}

Asep Kurnia. (2011). IImigran Ilegal Potret Penanganan dan Pencegatan dalam Perspektif Sistem Manajemen Nasional, Jakarta: IOM.

Alan Allport, John E. Ferguson Jr. (2009). Immigration Policy, $2^{\text {nd }}$ Edition, New York: Chelsea House Publishers.

Andrew C. Sobel (ed). (2009). Challenges of Globalization Immigration, Social Welfare, Global Governance, London - New York: Routledge.

A.W. Bradley, K.D. Ewing. (2007). Constitutional and Administrative Law, $14^{\text {th }}$ 
Ed, Harlow (England): Pearson Education Limited.

Bagir Manan. (1996). "Memantapkan Peranan Imigrasi Dalam Pelayanan, Penerapan dan Penegakkan Hukum Keimigrasian Pada Era Globalisasi”, makalah, disampaikan pada Rapat Kerja Direktorat Jenderal Imigrasi, Departemen Kehakiman, Jakarta, 21 Agustus. (1992). Dasar-Dasar Perundang-undangan Indonesia, Jakarta: Ind-Hill.Co. . (2000). "Hukum Keimigrasian dalam Sistem Hukum Nasional", makalah yang disampaikan pada Rapat Kerja Nasional Keimigrasian, Jakarta: Ditjend Keimigrasian Departemen Hukum dan Perundang-undangan, 14 15 Januari.

Bilal Dewansyah.(2013). Pencegahan dan Penangkalan dalam Perspektif Hak Atas Kebebasan Bergerak Setelah Perubahan UUD 1945, tesis, Bandung: Program Magister Ilmu Hukum FH Unpad.

Catherine Dauvergne (2008). Making People Illegal What Globalization Means for Migration and Law, Cambridge - New York : Cambridge University Press.

Fajri Nusyamsi, dkk. (2012). Catatan Kinerja DPR 2011, Legislasi: Aspirasi atau Transaksi?, Jakarta: PSHK.

Guy S. Goodwin Gill. (1978). Internasional Law and Movement of Persons Between States, Oxford : Clarendon Press.

H.R.T. Sri Soemantri M. (2014). Hukum Tata Negara Indonesia Pemikiran dan Pandangan, Bandung: Remaja Rosdakarya.

HukumOnline. (2011). "UU Keimigrasian Akhirnya Disahkan", Kamis, 07 April, http://new.hukumonline.com/berita/ baca/lt4d9d70fc099bd/uu-keimigrasian-akhirnya-disahkan. [Diakses 30 Juni 2015].
IOM. (2012). Petunjuk Penanganan Tindak Pidana Penyulundupan Manusia: Pencegatan, Penyidikan, Penuntutan dan Koordinasi di Indonesia, Jakarta:, IOM Misi Indonesia.

James P. Lynch, Rita J. Simon. (2003). Immigration The World Over Statutes, Policies, And Practices, Lanham: Rowman \& Littlefield Publishers.Inc.

Jo-Anne Pemberton. (2009). Sovereignty: Interpretations, Hampshire - New York: Palgrave Macmilan.

Khudzafiah Dimyati \& Kelik Wardiono (ed). (2001). Problema Globalisasi Perspektif Sosiologis Hukum, Ekonomi, \& Agama, Cetakan Ke-2, Surakarta: Muhammadiyah University Press Universitas Muhammadiyah Surakarta.

Moh. Mahfud MD. (2006), Membangun Politik, Menegakkan Konstitusi, Jakarta: LP3ES.

M. Iman Santoso. (2004). Perspektif Imigrasi Dalam Pembangunan Ekonomi dan Ketahanan Nasional, Jakarta: UI Press. (2007). Perspektif Imigrasi dalam United Nation Convention Against Transnational Organized Crime, Jakarta: Perum Percetakan Negara - RI.

Noha Shawki and Michaelene Cox (ed). (2009). Negotiating Sovereignty and Human Rights Actors and Issues in Contemporary Human Rights Politics, England: Ashgate.

Rakyat Merdeka Online. (2011). "UU Imigrasi Disahkan, Pemerintah Tak Lagi Diskriminatif Terhadap Kawin Campur", Kamis, 07 April, tersedia dari http:// www.rmol.co/read/2011/04/07/23499/ UU-Imigrasi-Disahkan,-PemerintahTak-Lagi-Diskriminatif-TerhadapKawin-Campur-. [Diakses 30 Juni 2015].

Republika. (2003), “10.593 Kasus Imigran Ilegal Masuk Perairan Indonesia”, 
tersedia dari http://www.republika. co.id/berita/nasional/jawa-tengah-diynasional/13/11/06/mvuci6-10593-kasus-imigran-ilegal-masuk-perairan-indonesia. [Diakses 23 November 2013].

Ridwan Arifin. (2013). "Bom Waktu Imigran Gelap di Indonesia”, Kompasiana, tersedia dari http://www.kompasiana. com/ridwan-arifinjazz/bom-waktuimigran-gelap-di-indonesia 552a87 94f17e617e17d62438. [Diakses 29 November 2013].

Susi Dwi Harijanti, Rahayu Prasetianingsih, Bilal Dewansyah. (2007). Politik Hukum Kewarganegaraan Indonesia, Laporan Akhir Penelitian, Bandung:
Fakultas Hukum Unpad.

Stephen D. Krasner. (1999). Sovereignty: Organized Hypocrisy, Pricenton: Pricenton University Press.

Satvinder Singh Juss. (2006). International Migration and Global Justice, England-USA: Ashgate Publishing Limited-Ashgate Publishing Company.

Sam Fernando. (2013). "Politik Hukum Pemerintah (Direktorat Jenderal Imigrasi) Dalam Menanggulangi Masalah Penyelundupan Manusia”, tersedia dari http://hukum.ub.ac.id/wpcontent/uploads/2013/04/Jurnal-SamFernando.pdf. [Diakses pada 23 Maret 2014]. 